Conference Paper

\title{
Analysis of Stock Prices Before and After the Pandemic on Banking in Indonesia
}

\author{
Heliani*, Nurul Setia Rahayu, Randi, Rida Fitriana, Junaedi Siswanto \\ Nusa Putra University, West Java 43155, Indonesia
}

*Corresponding author:

E-mail: heliani@nusaputra.ac.id

\begin{abstract}
Covid-19 not only has an impact on the health sector but Covid-19 also has an impact on the economic sector in Indonesia. This study aimed to analyze how Covid- 19 affects the decline in share prices in Indonesian banks from before, at the peakand after Covid-19, the sample banks include the Asian Central Bank (BCA), Bank Rakyat Indonesia (BRI), Bank Negara Indonesia. (BNI) and Bank Mandiri. The stock price before Covid-19 was said to be quite stable, while at the peak of the pandemic, the price of sham had decreased which caused investors not to invest their funds because they were considered not profitable. Because with the emergence of the Covid19 pandemic, many banking companies in Indonesia experienced a very significant decline in share prices, a comparative analysis was carried out on the decline in share price value. so that the title of the determination this time is about Stock Price Analysis Before and After the Banking Pandemic in Indonesia. The research method used in this research is a qualitative research method that contains comparative analysis. In this determination, it was concluded that the Covid-19 pandemic could affect the level of supply and demand which resulted in a decrease in the value of share prices in each bank.
\end{abstract}

Keywords: Share prices, covid-19 pandemic, banking

\section{Introduction}

Coronavirus is a new type of virus, namely a severe acute respiratory syndrome virus, this virus attacks human immunity, Covid-19 not only attacks the health sector but Covid-19 has an impact on the world economic sector including Indonesia, which feels the impact of this Covid-19. Macroeconomic changes in Indonesia will certainly have an impact on the national economy and all industries, for example, high exchange rates and the ups and downs of stock prices due to the Covid-19 outbreak. The decline in share prices in banks will also have an impact on the decline in the stock price index on the Indonesia Stock Exchange (IDX) and have an impact on the level of investment in the capital market. Also, the phenomenon that occurred was that the stock price index worldwide fell drastically and the JCI in Indonesia fell sharply and touched the lowest level at Rp 3,911.71.

Banking is one of the economic activities that play an important role in contributing to the JCI value on the IDX. Banking in an economy plays a role in collecting and distributingfunds to the public. However, the occurrence of covid-19 limits the distribution of credit from a bank. Bank samples taken in this share price comparison include the Asian Central Bank (BCA), Bank Rakyat Indonesia (BRI), Bank Negara Indonesia (BNI), Bank Mandiri. The reason for taking the sample of banks was that these banks were familiar among the Indonesian people and were also banks listed on the Indonesia Stock Exchange (IDX), making it easier to find the data needed and also the reason for taking the sample because of the value of the stock prices of the banks. has decreased significantly. such as business activities that include institutions to carry out business activities. According to Husnan (2008) "Shares are securities owned by investors to show ownership/rights of part of the assets of the organization, shares are also issued to investors so that investors can exercise theirrights". Meanwhile, according to Fahmi (2012) "in the stock capital market is an investor's strategy that can get feedback. In shares, there is the name of the company, the nominal value, and the rights and obligations as outlined on a sheet.

How to cite:

Heliani, Rahayu, S., Randi, Fitriana, R., \& Siswanto, J. (2021). Analysis of stock prices before and after the pandemic on banking in Indonesia. 1st ICEMAC 2020: International Conference on Economics, Management, and Accounting. NST Proceedings. pages 98-101. doi: 10.11594/ nstp.2021.1011 


\section{Literature Review}

According to Kasmir (2013) in the book Financial Statement Analysis.activities in banking include landing (channeling funds) and funding (raising funds). According to Darmawi (2012) in the Banking Management book. Banking is all activities that exist within the bank, such as business activities including institutions for conducting business activities. According to Husnan (2008) in the book Financial Management "Shares are securities owned by investors to show ownership/rights to part of the organization's assets, shares are also issued to investors so that investors can exercise their rights". Meanwhile, according to Fahmi (2012) in the stock capital market is an investor's strategy that can get feedback. In shares there is the name of the company, the nominal value and the rights and obligations which are stated on a sheet of paper for each holder.

The share price is a nominalamount in the form of rupiah, this share price can be formed due to offers and purchases made by stock exchange members (Hadi, 2013).

According to Darmadji and Fakhrudin (2012) in the book Capital Market in Indonesia say that the definition of stock prices is "Supply and demand affect the ups and downs of stock prices, stock prices can change in minutes, even in seconds, this is influenced by the supply and demand that occurs between buyers. and stock sellers. Meanwhile, Myers and Majluf (1984) in Robert A. Korajczyk in the book Qualitative Reaserch, stated that "differences in information between companies and shareholders can affect fluctuations in the value of stock prices, because investors are no longer interested in investing their funds because of their quality. the company becomes low so that this is considered to cause investors to suffer losses. The stock price movements can be divided into three, namely:

1. The first is the stock price which continues to rise from time to time, this condition is called Bullish. This situation was caused by the company's management policies and global financial conditions.

2. The second is Bearish, which is a condition in which the stock price has decreased continuously so that it has an impact on losses experienced by investors.

The third sideways is a condition where the stock price is at a stable point, what is meant by stable here is that the stock price moves up and down to form a horizontal chart from time to time. The Covid19 pandemic has had a significant impact on the decline in share prices, the impact of the Covid-19 pandemic is not only felt by companies in Indonesia but the impact of the Covid-19 pandemic is also felt by companies around the world because during the Covid pandemic -19 the economy in Indonesia as well as around the world has experienced a very significant decline. With this decline in share prices, investors assume that if they invest in the Covid-19 pandemic, it will not benefit them, because at the peak of the Covid-19 pandemic, the economy around the world can be said to be experiencing bearishness or a decline in stock prices. continuously.

\section{Hypothesis}

There are differences in the price of banking shares in Indonesia, stock prices before, peak and postpandemic Covid 19.

\section{Methodology}

This measurement uses quantitative research methods which currently contain comparative analysis. The data used in this research is secondary data. The data is in the form of covid-19 stock price data (November 2019 - February 2020) because in those months Covid-19 has not shown the impact of changes in the value of stock prices, at the peak of Covid-19 (March - May 2020) because in those months Covid-19 began to have an impact on changes in the value of stock prices and after the peak of Covid-19 (June - October 2020) in these months the value of share prices began to stabilize. The data used in this study issecondary data, the data source obtained in this study was obtained online from the idx.co.id website because this data is the most relevant. The sample used in this study were several banks listed on the IDX, including Bank Mandiri, Bank Sentral Asia (BCA). 


\section{Methodology Research Instruments}

With the formula:

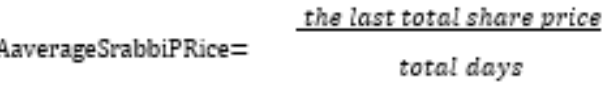

To see if there is a difference in the share price of Indonesian banking before (November 2019 February 2020), peak (March-May 2020) and after (June - October 2020) the peak of Covid-19, the average share price value of each bank is taken.

\section{Results and Discussion}

To calculate the value of the share price during the pandemic, the average share price was calculated starting from before, during the peak and after Covid, by adding the last share price from the beginning of November 2019 - the end of February 2020 divided by the number of days.

A significant difference in the share price of a bank can be seen from figure 1 that the peak of Covid19 affected stock prices before Covid-19, as the data above can be concluded that at the peak of Covid19, the price of banking shares in Indonesia experienced a very significant decline. At the time before the Covid-19 pandemic, the share price of each bank could be said to have a fairly stable share price value, because at the time before this pandemic each bank was still in a normal economy.

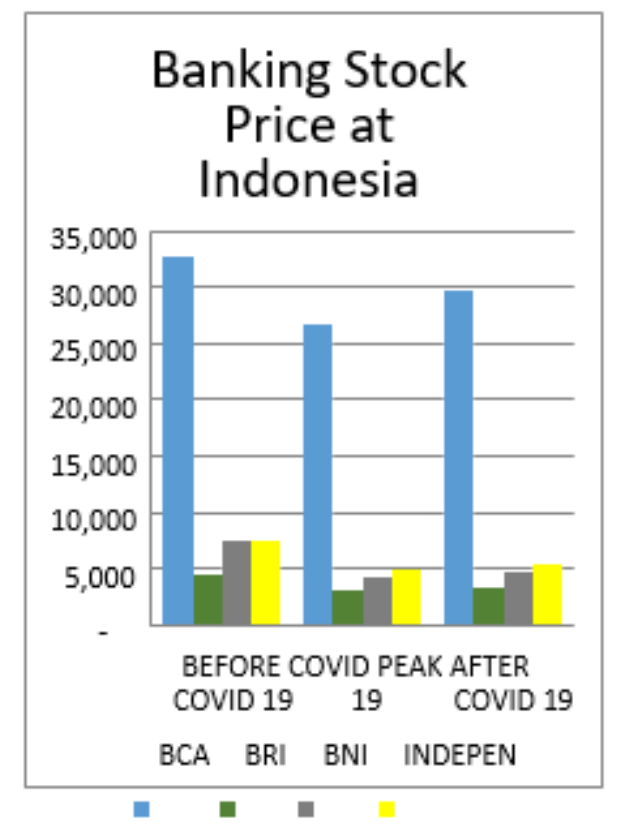

Figure 1. A significant difference in the share price of a bank

However, there was a problem at the peak of the pandemic because at that time it could be said that investors did not want to invest their funds because they were considered not providing benefits for each investor, thus making investors reluctant to channel their funds to banks.

At the peak of the pandemic, investors also did not have the interest to make purchases on the stock exchange so that demand decreased and caused the share price to also decrease, because investors thought the company was not of low quality. After the peak of the pandemic passed, the share prices of each bank began to rise again because the economy had begun to rebound and investors had started channeling their funds to each of these banks so that the share price of each bank began to rise from its lowest point. 
This proves that the value of the stock price is strongly influenced by the high and low levels of supply and demand for every investor who buys shares on the stock exchange.

Covid-19 is a virus that has an impact not only on the health sector butalso on the economic sector, one of which is stock prices in banks. Banking is one of the economic activities that plays an important role in contributing to the JCI value on the IDX. Banking in an economy plays a role in collecting and distributing funds to the public. However, the occurrence of covid-19 limits credit distribution from a bank. From the research, stock prices before, peak and after the peak of Covid-19 in the banking sector experienced a significant decline due to a significant decrease. The share price is an entity for a company because shares are alternative funding for companies that ultimately sell these shares due to several factors.

In an economy, the ups and downs of stock prices are normal because stock prices are influenced by supply and demand in a market. For example, if the demand for capital is high, the stock price will rise, and vice versa, if the supply in the capital market increases, the share price will decrease. In general, share prices have increased and decreased due to several factors in a company, including internal and external factors.

Covid-19 is an external factor in the decline in share prices during the pandemic, the decline in share prices was caused by several things, including the massive spread of Covid-19 in early 2020 which caused global economic activity to decline. This is a negative impact of the coronavirus so that buying and selling activity also decreases, and with the decrease in interest rates by the Central Bank of the United States, the Federal Reserve also causes a decline in stock prices. The Fed decided in early March 2020 to cut prices from interest rates to 50 basis points from $1.00 \%$ to $1.25 \%$. Stock prices are elastic, meaning that the stock price can fluctuate but it does not rule out the possibility of the stock price returning to its original price. The reason investors do not want to invest during this pandemic is that investors think that investing in this pandemic period is not profitable.

\section{Conclusion}

Based on the explanation above, it can be concluded that during the Covid-19 pandemic, the price of banking shares in Indonesia experienced a significant decline, this can be seen from the results of research on share prices at banks before, at the peak, and after. Covid19. The share price in each bank is also influenced by the high and low levels of supply and demand for each investor. If investor demand increases, the stock price will rise, but if demand is low and supply is high, the value of the share price will decrease. So, it can be concluded that the high and low value of the stock price is influenced by the many levels of demand and supply of investors. The reason investors do not want to invest during this pandemic is that investors think that investing in this pandemic period is not profitable. For further research, the researcher can add samples and the research period can be extended to get better and more accurate results.

\section{Acknowledgment}

This research can be carried out well with the help of various parties, for that the researcher would like to thank the supervisor, the IDX Indonesia Stock Exchange, and previous researchers who have provided information so that this research can be completed well and smoothly.

\section{References}

Darmadji, T., \& Fakhruddin. (2012). Pasar modal di Indonesia. Edisi ketiga. Jakarta: Salemba Empat.

Fahmi, I. (2012). Analisis kinerja keuangan. Bandung: Alfabeta

Hadi, N. (2013). Pasar modal: Acuan teoretis dan praktis investasi di instrument keuangan pasar modal. Yogyakarta: Graha Ilmu.

Husnan, S. (2008). Manajemen keuangan: Teori dan penerapan buku 1 edisi 4. BPFE: Yogyakarta.

Kasmir. (2013). Analisis laporan keuangan. Rajawali Pers: Jakarta. Darmawi,

Myers, S. C., \& Majluf, N.S. (1984). Corporate financing \& invesment decision when firm have information that investor do not have. Journal of Financial Economics, 13, 187-221. 